Article

\title{
The Catholic Bishops vs. the Contraceptive Mandate
}

\author{
Leslie C. Griffin \\ UNLV Boyd School of Law, University of Nevada, Las Vegas, NV 89154, USA; \\ E-Mail: leslie.griffin@unlv.edu; Tel.: +1-702-895-2071 \\ Academic Editor: Timothy A. Byrnes
}

Received: 31 October 2015 / Accepted: 13 December 2015 / Published: 18 December 2015

\begin{abstract}
The Roman Catholic bishops of the United States have publicly opposed artificial contraception since they first issued a public statement condemning it in 1919. Thereafter, the bishops were generally unsuccessful in persuading the public that contraceptive access should be restricted. Recently, however, the bishops succeeded in a campaign to restrict access to contraceptives for Catholic and non-Catholic women alike. Their lobbying and public criticism of the contraceptive mandate of the Affordable Care Act (ACA), which requires employer health plans to offer preventive reproductive care coverage, forced Obama administration officials into a series of accommodations that gutted portions of the law intended to provide contraception to employees without copayment or cost sharing. In contrast to their earlier efforts to restrict reproductive freedom, the bishops successfully characterized their efforts against the ACA as a battle for religious freedom rather than against reproductive rights. This successful strategy may lead to future setbacks for women's reproductive liberty.
\end{abstract}

Keywords: first Amendment; contraception; bishops; Religious Freedom Restoration Act; Affordable Care Act; contraceptive mandate

\section{Introduction}

As representatives of the Roman Catholic Church in the United States, the American Catholic bishops have consistently counseled that the use of artificial contraception is never permitted. They have also vocally opposed any and all public policies that permitted contraceptive use by anyone, whether Catholic or non-Catholic, American or foreign. The bishops' first joint public statement condemning contraception appeared in 1919, when they stepped into a more public role to counter the 
successes of Margaret Sanger's birth control movement. Thereafter, however, the bishops were generally unsuccessful in persuading the public that contraceptive access should be restricted. Legal and political developments of the 1960s, including the Supreme Court's 1965 decision in Griswold vs. Connecticut invalidating state restrictions on contraception, especially thwarted bishops' efforts to stop contraceptive use and availability.

Recently, however, the bishops succeeded in a campaign to restrict access to contraceptives for Catholic and non-Catholic women alike. Their lobbying against and public criticism of the contraceptive mandate of the Affordable Care Act (ACA), which requires employer health plans to offer preventive reproductive care coverage, forced Obama administration officials into a series of accommodations that gutted portions of the law intended to provide contraception to employees without copayment or cost sharing.

In contrast to their earlier efforts to restrict reproductive freedom, the bishops successfully characterized their efforts against the ACA as a battle for religious freedom rather than against reproductive rights. Through litigation they worked in conjunction with a broad range of Catholic institutions - universities, colleges, dioceses, hospitals, and parishes - that buttressed their religious freedom argument. This allowed them to achieve legal and political success even though a majority of their membership - i.e., individual Catholics - continues to use contraception as well as support contraceptive access for employees. Moreover, in the 2010s - as opposed to the 1910s - the bishops' anti-contraceptive drive presented a common front with evangelical Christians that was unimaginable at the turn of the twentieth century.

\section{The Bishops' Twentieth-Century Failures to Restrict Contraception}

At the beginning of the twentieth century, the American Catholic bishops inhabited a church-friendly regime of anti-contraceptive laws due to no effort of their own. In 1873, influenced by the campaign of Congregationalist Protestant Anthony Comstock, who opposed prostitution, pornography, contraception and advertisements for contraceptives, the federal government passed a law forbidding sending through the mails "any drug or medicine or any article whatever for the prevention of conception." The states quickly mimicked the federal law by drafting their own "mini-Comstock laws" to restrict contraceptive advertisement, counseling, prescription and use. The Comstock laws fined or imprisoned anyone who sold or distributed contraceptives, or advertised or disseminated information about contraception ([1], pp. 104-7). Margaret Sanger challenged those laws by opening the first birth control clinic in 1916.

The American Catholic bishops organized as the National Catholic Welfare Conference (NCWC) during the 1910s. As a group they increasingly opposed Sanger's and others' efforts to provide birth control to women. The "bishops' omnibus pastoral letter of 1919...included the American episcopate's first collective public statement condemning contraception." ([2], p. 41).

During the 1910s and 1920s many Protestant Americans viewed Catholics with distrust and suspicion. It was difficult for the bishops to find allies against Sanger even though Protestants shared their moral disapproval of contraception. Nonetheless, the bishops resolutely lobbied against state and federal efforts to update the restrictive Comstock laws. Aware of their image problem, they sought to use "newly enfranchised [Catholic] laywomen" as their public face for testimony against federal and 
state legislation, even though the bishops had opposed the Nineteenth Amendment, which gave women the right to vote in 1920 ([2], p. 56). When supporters of birth control sought to recruit individual Catholics to their side, the bishops' active participation in the public debate became not only a means to influence public policy but also a way "to catechize their own faithful" about contraception's immorality ([2], p. 124).

The unified Christian perspective on contraception eroded in the 1930s after the Anglican Church allowed responsible contraception by married couples ([3], pp. 137-39).With increasing acceptance of birth control in the Protestant churches, opposition to contraception became perceived as a Catholic issue. No matter how isolated their argument from other Christians, however, the bishops remained committed to the cause. During the Second World War, for example, church leaders were appalled by the federal government's policies providing condoms to soldiers in the fight against venereal disease. The bishops even considered issuing a ruling that Catholics could not serve in the military because the army's condom policy made World War II unjust ([2], p. 165). At war's end, the bishops fought to block contraception from public hospitals and from being provided overseas as part of U.S. foreign aid ([2], p. 165).

By the 1950s and 1960s, however, it was "painfully evident that Catholics had few allies when it came to contraception, and none who shared their particular moral logic" ([2], pp. 163-64). By then the bishops' political and legal battle focused on countering efforts to modify or repeal the state Comstock laws. Massachusetts and Connecticut - with their large Catholic populations - had some of the most restrictive Comstock laws. The bishops fought valiantly to keep those laws in place. Twice during the 1940s their political clout in Massachusetts defeated referenda to reform the anti-contraceptive laws ([3], p. 141). Thus their efforts "prevent[ed] the opening of public birth control clinics in northeastern cities that served largely immigrant and poor populations, blocked state legislatures from legalizing birth control, and turned back efforts to provide federal funding for family planning programs for the poor", even though their theological reasoning against contraception's morality was not shared by most Americans ([4], p. 54).

Gene Burns has persuasively argued that during those years the bishops exercised a "moral veto", i.e., stopped change in the legislative process and maintained the status quo of the Comstock laws ([3], p. 141). The bishops' perceived connection to a bloc of Catholic voters and their willingness to lobby against contraception may have persuaded both Catholic and non-Catholic legislators to avoid the issue of contraception for fear of offending Catholic voters. Thus the bishops were able to veto, block or delay contraceptive reform despite their inability to persuade a majority of voters to share their belief that contraception was immoral.

The U.S. Supreme Court took the issue of the mini-Comstock laws away from state legislators in Griswold v. Connecticut (1965) [5], which recognized a constitutional right of marital privacy to use contraceptives, and Eisenstadt v. Baird (1972) [6], which extended the privacy right to contraceptive use to unmarried individuals. Estelle Griswold, Executive Director of the Planned Parenthood League of Connecticut, won the right to keep her birth control clinic open by a 7-2 vote of the Justices; the majority included the Court's only Roman Catholic, Justice William Brennan [5].

Because of the Second Vatican Council, by 1965, the internal politics of the church had changed from earlier eras, forcing the bishops to focus more on internal church governance than on external law and politics. During the many years of the birth control movement that started with Margaret Sanger 
and culminated in Griswold, many Catholics began to use artificial contraception despite their church's prohibition. In 1951, Pope Pius XII had authorized the natural rhythm method of birth control for Catholic married couples, thus opening the door to the idea that every sexual act need not be fecund as well as raising the question why natural methods were preferable to medical ones ([2], pp. 204-63; [3], pp. 137-41). A devout Catholic, Harvard Medical School's Dr. John Rock, led the scientific efforts in the United States to produce "The Pill." Rock, who started his career in a rhythm-method birth control clinic, gradually decided that women should have access to birth control because "compassion for his patients overwhelmed his compulsion to toe the Church's line." [7]. As far back as 1931, Rock was one of fifteen Boston doctors (and the only Catholic) to sign a petition calling for the repeal of the state's ban on contraception." "I don't think that Roman Catholicism forces a man to interfere with other people's freedom of conscience and action within their own moral principles," he told Time Magazine in 1948 [7].

Rock spent years writing books and giving numerous press interviews trying to persuade his church that the pill (which mimicked women's reproductive cycles) was just as natural as the rhythm method and should be accepted. Another Catholic, Dr. Pasquale DeFelice, an obstetrician-gynecologist completing his residency at Georgetown University Medical Center, approved Rock's application for Food and Drug Administration (FDA) approval of the pill in 1960 [7]. Thereafter American Catholic women — whose family and health needs had prompted Rock's research in the first place — increasingly used artificial contraception in addition to the rhythm method, thus undermining the bishops' calls for legal bans on artificial contraception.

The election of Pope John XXIII to the papacy in 1958 and his convocation of the Second Vatican Council ("Vatican II") in Rome in 1962 also led many American Catholics to believe that authorities in a modernizing church would lift the prohibition against artificial contraception ([2], pp. 204-63). Ecclesial and political debates in Massachusetts reflected the change in climate caused by Vatican II. In 1965, Massachusetts considered new legislation that would allow doctors to prescribe contraception and other health personnel to distribute contraceptive information to married persons. During the 1940s, Archbishop Richard Cushing of Boston had successfully led two campaigns to defeat referenda to repeal the state's Comstock laws, praising the anti-contraception laws because they "explicitly tied the state's law to God's law." ([8], p. 161). In 1965, however, then-Cardinal Cushing testified that he would not oppose the new law. "Catholics do not need the support of civil law to be faithful to their own religious convictions and they do not seek to impose by law their moral views on other members of society," he wrote ([8], p. 162). Cushing even endorsed the pro-contraception bill as a matter of religious liberty.

Cushing's new reasoning was influenced by the theologian and Jesuit priest John Courtney Murray, a New Yorker who played a dominant role in drafting the church's statement on religious liberty at Vatican II. Before the Council, the church had long taught that only Catholics should enjoy the civil right to religious freedom because only Catholicism is true and erroneous religions should have no rights. This teaching had bedeviled the American church; the First Amendment guarantees everyone's religious freedom. Presidential candidate John F. Kennedy had famously distanced himself from this aspect of his church's teaching in a campaign address to Baptist ministers in Houston, Texas, during the 1960 presidential campaign ([9], pp. 213-14). Without doing so, he probably would not have been elected president. 
Many European bishops wanted the church to ratify this traditional teaching at the Council. The American bishops, however, pushed for a change in church teaching that would be more consistent with the American situation. In Dignitatis Humanae, which the church's bishops ratified at the last session of the Council in December 1965, the church adopted Murray's argument that religious freedom is a universal right required by the dignity of the human person ([10], p. 451).

The changed interpretation of religious freedom had repercussions in the area of contraception. In a memo to Cardinal Cushing advocating support of the new Massachusetts birth control law, Murray concluded that because Americans of different religions disagree in good faith about the morality of contraception, "laws in restraint of the practice [of contraception] are in restraint of religious freedom." ([11], p. 81; [12]). The preconciliar tradition of tying the state's law to God's law without regard for the rights of non-Catholics had disappeared... for the time being.

Although the bishops at Vatican II addressed a wide range of important issues, they did not address the morality of artificial contraception. Instead, the topic was referred to a papal commission, which voted in 1967 for the church to retract its ban on artificial contraception. In July 1968, however, Pope Paul VI ignored the advice of his own commission and released Humanae Vitae, the encyclical letter that reiterated the church's traditional ban on artificial contraception ([2], pp. 204-63).

The encyclical letter's repercussions in the United States were catastrophic. Led by Fr. Charles Curran of Catholic University, many prominent theologians and lay American Catholics vocally protested the papal decision. For many years after 1968, the bishops were preoccupied with providing a persuasive anti-contraceptive argument to their flock and disciplining Catholics who dissented from the church's teaching. Meanwhile, Catholic priests, who serve the role of confessors in the church, struggled with their pastoral duties toward the large numbers of women who were now grave sinners in the church's eyes ([2], pp. 264-79). American Catholic women had started to use contraception in numbers that match their non-Catholic counterparts, and continue to do so now [13].

In the wake of Vatican II, for a brief time at the end of the 1960s, Catholic authorities could respect the religious freedom of non-Catholics to use contraception, downplay their political goal to make their own moral law the civil law for everyone else, and focus on the pastoral needs of their members. Abortion, however, soon thrust the bishops back into politics, and, eventually, provided them with the opportunity to put contraception back into the political and legal spotlight.

\section{The Bishops' Expanded Political Role}

In 1967, the American bishops reorganized the NCWC into the National Conference of Catholic Bishops (NCCB), known today as the United States Conference of Catholic Bishops (USCCB), which gave them a new entry into the political arena and a stronger voice in confronting politicians ([2], p. 257). At the same time that the American bishops dealt with internal church dissent over contraception, they also took center stage in the nation's political and legal debate over abortion.

Many politicians wanted the bishops' ears and, more importantly, the votes of their members, and they frequently believed (without persuasive evidence) that the bishops could deliver the Catholic vote. In the 1970s, some Republican politicians, led by President Richard Nixon, believed that anti-abortion Catholic voters might defect from the Democratic Party to create a new Republican majority [14]. Those Republican politicians and their evangelical Christian allies no longer advocated the 
anti-Catholicism of the 1930s, when Protestants questioned Catholics' loyalty to the United States. Instead, Catholics - who were rapidly becoming the largest religious denomination in the United States - offered evangelical Christians a path to political power and the hope of turning back the clock on abortion and other reproductive rights.

In 1976 - the year of the first presidential campaign after the Supreme Court recognized a constitutional right to abortion in Roe v. Wade - the bishops presented litmus test questions about abortion to President Gerald Ford and Governor Jimmy Carter, threatening to withhold Catholic votes until the candidates sided with the bishops and rejected Roe entirely. During the 1970s and 1980s, according to Timothy Byrnes:

Unlike their predecessors, these bishops have not been branded un-American or dismissed as antidemocratic threats to constitutional government. To the contrary, the bishops' visible religious identify and unapologetic moral assertiveness have made them attractive potential allies to a wide range of political forces. Anxious to attract Catholic voters, exploit Catholic resources, and apply a religious gloss to their own partisan programs, candidates and party leaders have sought the bishops out, engaged the bishops in political discussion, and highlighted the bishops' moral agenda ([15], p. 5).

By 1984, the Republican Party and the bishops were allied against reproductive freedom; the bishops repeatedly attacked Roman Catholic Representative Geraldine Ferraro, the Democratic nominee for vice president, for her support of reproductive liberty, and Catholic politicians like Governor Mario Cuomo of New York, who had suggested in a famous speech at Notre Dame that Catholic politicians could support abortion rights. Ferraro and Cuomo used arguments similar to John Courtney Murray's reasoning about contraception, namely that in a pluralistic society whose citizens had differing moral perspectives on abortion, respect for religious freedom prohibited Catholics from imposing their own views on everyone else ([15], pp. 119-21).

The bishops did not agree with the politicians, and returned to the preconciliar idea that the civil law of the state must be equivalent to the moral teaching of the church. From 1984 to 2015, public opposition to abortion received most of the bishops' political energy. Although they occasionally dialogued with the American public about nuclear weapons, just war, and protection of the poor, there was no dialogue on abortion. The bishops were unyielding in their position that direct abortion must never be legal, even in cases of rape, incest, or threats to the life and health of the mother, just as the church taught. (The church allowed medical procedures like organ removals that indirectly caused abortion.)

The USCCB developed a political powerhouse in Washington, D.C., with the following mission statement:

The Conference seeks to unify, coordinate, encourage, promote, and carry on Catholic activities in the United States; to organize and conduct religious, charitable, and social welfare work at home and abroad; to aid in education; to care for immigrants; and generally to further these goals through education, publication, and advocacy. To that end, the Conference provides and promotes a wide range of spiritual, educational, and charitable services throughout this country and around the world [16]. 
The USCCB is a tax-exempt, nonprofit $\S 501(\mathrm{c})(3)$ organization, which, in order to keep its tax-exempt status, must not devote a "substantial amount" of time to lobbying. According to IRS regulations, "Lobbying includes trying to influence legislation by Congress, state legislatures, or by public referenda and ballot initiatives, but not executive, judicial or administrative action. Churches may, however, get involved in issues of public policy in an educational manner." ([17], p. 6).

By 1990, the Conference had accumulated an annual budget of $\$ 30$ million for "[c]ongressional testimony, litigation, lobbying, media outreach, monitoring of federal legislation and regulation, participation in federal regulatory proceedings, conferences and seminars, educational ministry, pastoral letters, publications, domestic and international relief services, and grassroots organizing." ([4], p. 139). It had four full-time lobbyists with a lobbying budget of $\$ 500,000$, and the Secretariat of Pro-Life Activities had a $\$ 300,000$ budget ([4], p. 139). The Conference also had a sophisticated Government Relations office that "coordinate[d] and direct[ed] the legislative activities of the USCCB staff and other church personnel to influence the actions of the Congress. A specific set of issues [wa]s assigned to each congressional liaison staff person, who in turn, work[ed] in collaboration with particular policy departments at the USCCB." [18].

The bishops have walked a tightrope between their lobbying and educational advocacy activities. Federal law prohibits non-profits like the USCCB from engaging in a "substantial amount" of lobbying. In the Pew Forum's 2011 report on Lobbying for the Faithful: Religious Advocacy Groups in Washington, D.C., the USCCB stood out among religious lobbyists for refusing to separate its lobbying budget from its advocacy expenditures. Without this budgetary information, the public has no precise idea of just how substantial the USCCB's lobbying activity is. The Pew Forum eventually removed the USCCB from its reports because the Conference's numbers concealed more than they revealed [19].

In fairness to the bishops, disclosure might not make a difference. Galle observes that there "is no clear law on what comprises a 'substantial' amount of lobbying," ([20], p. 372), and the IRS is reluctant to take on powerful churches. Complaints to the IRS about the bishops' lobbying and other political activities have gone unanswered. No one doubts, however, that politicians listen when the USCCB comes calling. And they always come calling about contraception and abortion.

\section{Precursors to the Contraceptive Mandate of the Affordable Care Act}

During the 1960s and 1970s, Griswold and Eisenstadt established a legal regime that favored contraceptive use as a constitutional right. During the 1990s, however, women's health advocates effectively demonstrated that many American women lacked access to contraception because their insurance did not cover it. Women also paid more than men for health care because of the higher costs of reproductive services for women. The inequality became especially apparent and objectionable once the public discovered that many insurers funded Viagra for men but not contraception for women ([21], pp. 110-11).

In response to this systemic inequality in health care, between 1996 and 2009 twenty-six states passed "contraceptive equity acts" to give women equal access to reproductive health care [22]. Those acts required insurance plans that offer prescription drug plans to include contraceptive drugs and devices in their coverage. The California legislature, for example, enacted the Women's Contraception 
Equity Act in order to protect "health and safety concerns" as well as "to promote and protect fundamental personal rights of individual employees to privacy and free expression, to free exercise of their respective religious and moral beliefs, and to equal protection in their access to prescription medications." [23]. New York passed similar legislation in 2002 [24]. Equivalent federal legislation, the Equity in Prescription Insurance and Contraceptive Coverage Act (EPICC), was considered by the United States Congress but never passed. Federal law would not address contraceptive equity until President Obama's Affordable Care Act passed the Congress in 2010 ([21], pp. 110-11).

Throughout the 1990s, the bishops lobbied against the proposed federal and actual state equity legislation. Women's contraception equity acts stalled in the legislatures of two of the largest states, California and New York, because of Catholic opposition, before eventually passing over the church's objections. The bishops first challenged the medical underpinning of the bills, arguing that while there is a medical need for Viagra, contraception is not "basic health care," but is "elective" and "non-therapeutic" and, therefore, not worthy of insurance coverage [25]. Unlike the 1960s, there was no talk of the bishops' respecting American women's right of religious freedom to choose contraception for themselves. Just like the pre-1960s era, the bishops viewed contraception completely as a moral issue and not even as a matter of medicine.

As in the past, however, the bishops' moral and pseudo-medical arguments against contraception were ineffective. Their alternative strategy was to lobby the legislatures for church exemptions from the insurance laws as a matter of religious freedom. They demanded that the exemptions apply, not only to Catholic parishes and dioceses, but also to all the church's schools, universities, hospitals and social service organizations as well as to all those organizations' Catholic and non-Catholic employees.

In California, the Catholic Church was the only religious group to lobby against the Women's Contraception Equity Act. Without its intervention, the legislation would not have included any exemption. In response to the church's concerns, however, the Act's sponsors included an exemption for religious employers, but an exemption much narrower than the church demanded. The legislature limited the exemption to religious employers "whose primary purpose is religious worship, religious teaching and religious service." In other words, churches, synagogues and mosques were exempt, but employers who offer secular services and serve non-Catholics were not. New York's exemption was similar to California's [23].

After the bishops' lobbyists failed to block the laws and receive the broad exemptions they desired, Catholic nonprofit organizations went to court, arguing that the First Amendment required the exemption that the legislatures had denied. Catholic Charities, a social service organization that receives most of its budget from federal and state funding and employs and serves numerous non-Catholics, led the litigation. It was during this state litigation that the bishops first honed in on the theme of criticizing contraceptive equity laws as "an unprecedented assault upon the religious freedom rights of the Catholic Church.” ([25], p. 1).

The bishops' strategy failed in the state courts, including the highest courts of New York and California, which ruled that under First Amendment law, neutral laws of general applicability like the women's contraceptive equity acts do not violate the Free Exercise Clause [23,24]. Those cases serve as an important reminder that the Free Exercise Clause of the First Amendment does not require religious exemptions for the bishops, the Catholic Church, Catholic Charities, Catholic universities and hospitals, or any of the church's numerous associates. As Roman Catholic Justice Antonin Scalia 
explained in the U.S. Supreme Court's leading free-exercise precedent, Employment Division v. Smith, all citizens, religious and non-religious alike, are obligated to follow "neutral laws of general applicability." [26]. As Justice Scalia explained,

Laws... are made for the government of actions, and while they cannot interfere with mere religious belief and opinions, they may with practices...Can a man excuse his practices to the contrary because of his religious belief? To permit this would be to make the professed doctrines of religious belief superior to the law of the land, and in effect to permit every citizen to become a law unto himself [26].

Because the contraceptive equity acts were clearly neutral laws of general applicability, the Catholic Charities' First Amendment challenges had to fail.

Thus in the late 1990s, although the bishops wanted to become a "law unto themselves" on contraceptive equity, their "assault on religious freedom" and total-exemption approach to contraception failed in the state legislatures and state courts. Their strategy was more successful once Obamacare became the law of the land in 2010.

\section{The Contraceptive Mandate of the Affordable Care Act}

Consistent with their church's teaching, the American Catholic bishops have long supported a human right to health care and advocated policies giving the poor access to health insurance. During the negotiations over the ACA in 2009 and 2010, however, the bishops held Congress hostage on the abortion issue, refusing their support for the entire bill as long any insurance policies might cover abortion. The bishops repeatedly drafted anti-abortion provisions and provided them to sympathetic Catholic members of Congress for implementation. It was only the intervention of several prominent Roman Catholic nuns, who run many of the nation's largest Catholic hospitals, which provided the political support that allowed the bill's passage over the bishops' objections [13]. As Representative Rosa DeLauro of Connecticut explained, the "Catholic bishops were willing to bring down the health care bill over the issue of abortion — even though the bill did not expand access to abortion.” [13].

Only after the ACA passed in March 2010 did contraception, rather than abortion, reemerge as a political and legal issue [13]. The ACA required insurance coverage for "preventive health services," which for women include reproductive care [27]. In order to implement that legislation, the Department of Health and Human Services (HHS) began its regulatory task of filling in the details of what "preventive health services" entail. HHS had barely announced its intention to do so in July 2010 - deferring the details until later — when the USCCB was lightning fast off the starting blocks to oppose any contraceptive coverage [28,29].

Through the notice and comment procedures required by federal law, HHS publishes proposed rules in the Federal Register and welcomes public comments on them. Even though HHS's first announcement on 19 July 2010 of its plan to define preventive services by August 2011 said nothing about contraception, the USCCB's Office of General Counsel (OGC) sent a letter to HHS warning department officials against any action to insure sterilization and contraception [28,29].

The letter to HHS introduced three arguments, the last two of which were ultimately successful in the bishops' campaign to weaken contraceptive coverage. First, OGC argued (as the bishops had in the 
states during the 1990s) that contraception is not a preventive service because pregnancy is not an illness or disease. In fact, General Counsel Anthony Picarello insisted, the use of contraception is bad for women's health! Second, the letter introduced the idea that some contraceptives cause abortion. Third, OGC demanded recognition for the church's conscience rights to deny contraceptives to employees, thereby picking the theme that the bishops would play over and over again, namely that the mandate was an "unprecedented threat to rights of conscience" - the same argument that had failed in the states during the 1990s ([29], p. 6).

Over the next five years, the bishops orchestrated a sustained campaign of public appearances, lobbied in Congress, commented on the regulatory process, and pursued extensive litigation to abolish the contraceptive mandate. By the time the first HHS regulations issued in August 2011, the bishops had already scored a victory. HHS had authorized the prestigious and nonpartisan Institute of Medicine (IOM) to identify the evidence-based preventive care services that are necessary to women's health. At IOM's recommendation, HHS instituted regulations requiring employer health care plans to cover twenty FDA-approved contraceptives as well as sterilization procedures and reproductive counseling. Among the required contraceptives were two types of intrauterine devices (IUDs), Plan B and Ella, which some critics later characterized as abortifacient, even though the medical community does not [30].

This August 2011 rule offered churches an exemption from the reproductive preventive services requirement even though the First Amendment does not require such exemptions for neutral laws of general applicability such as the ACA. HHS modeled its exemption on the state contraceptive laws, thereby freeing purely religious employers like houses of worship from the requirements, but otherwise applying the contraceptive regulations to both for-profit and nonprofit religious employers [31]. In the technical language of the regulations:

Only employers that meet all of the following criteria would be eligible for an exemption:

(1) The inculcation of religious values is the purpose of the organization.

(2) The organization primarily employs persons who share the religious tenets of the organization.

(3) The organization serves primarily persons who share the religious tenets of the organization.

(4) The organization is a nonprofit organization as described in Section 6033(a)(1) and Section 6033(a)(3)(A)(i) or (iii) of the Internal Revenue Code of 1986 [31].

In theory, there is no burden on reproductive liberty in this exemption because all church members "share the religious tenets of the organization," and thus no church employee will desire to use her insurance to purchase contraception. In the Catholic Church in the U.S., however, theory is at odds with practice because most Catholics dissent from their church's teaching on contraception [13]. HHS's initial regulation deprived the parish secretary or the lay minister of the ACA's protection, even though the purpose of the Act was to ensure that every American woman receives preventive reproductive services without copayment or cost sharing. Thus the exemption promoted only the bishops' religious liberty while completely disregarding the religious freedom of the bishops' employees. Although the government frequently referred to the reproductive rights of women, it never took into account the religious liberty of Catholic women to make their own decisions of conscience about contraception without the bishops' intrusion.

Nonetheless, the bishops' OGC was not grateful for the government's accommodation, immediately criticizing HHS's actions as inadequate to protect religious liberty [32]. The reaction clarified that the 
bishops' ultimate goal was to end contraceptive access for all Americans, and, if that was not possible, at least to extend complete exemptions to everyone morally opposed to contraception. The bishops' desired exemption would include not only religious and secular nonprofit and for-profit employers, but also individual employees who did not want to participate in an insurance plan that sponsored contraceptive coverage. According to the OGC,

The HHS mandate should be rescinded in its entirety. If HHS refuses to do that, then it must address the most grievous and intolerable aspects of this misguided mandate by (a) excluding from the mandate those drugs that can cause an abortion, and (b) exempting all stakeholders with a religious or moral objection to contraceptives, sterilization, and related education and counseling [32].

In exempting employees as well as employers, OGC's proposal undermined the whole structure of the ACA, which depends on having all insureds in the insurance pool [33]. Thus on the subject of contraception as well as abortion, the bishops were willing to eviscerate the ACA in the name of religious liberty.

In further reaction to the August regulations, in September the bishops launched a new Ad Hoc Committee for Religious Liberty, which included among its members a lobbyist. The mandate topped the list of the committee's concerns. ([4], p. 252; [13,34]). Two months later (on 10 November 2011), Belmont Abbey College, a Benedictine college in North Carolina, filed the first lawsuit challenging the regulations as a violation of the Religious Freedom Restoration Act (RFRA), the First Amendment, and the Administrative Procedures Act [35]. The college and the government agreed that the college was not exempt from the mandate "because it employs and serves many individuals who do not share its religious values and because it is not a church and does not otherwise qualify as an organization described in the relevant sections of the IRS Code." ([35], p. 29). But the college argued it should be exempt. Other lawsuits by religious nonprofits soon followed.

The political power of the bishops' opposition to the mandate was evident when President Obama invited Archbishop Timothy Dolan, the president of the bishops' conference, to a private November meeting at the White House to discuss the "religious liberty issue." [36]. Dolan reported that the president was "very sensitive" to the bishops' concerns about the mandate and "very ardent in his desire to assure me that this is something he will look long and hard at." [37]. Pressured by the bishops, the president considered revising the mandate before any court had invalidated it or his HHS had resolved the merits of the bishops' position for women employees. Acting exactly one year before his reelection, presumably the president believed that the bishops retained influence with Catholic voters, even though many Catholic observers had concluded that the bishops' moral and political authority was undermined by the church's cover-up of child sexual abuse by clergy.

The president's sensitivity to the bishops' concerns affected the litigation of the mandate. In court, the government argued that it was considering accommodations for religious nonprofits like Belmont Abbey. The legal cases were put on hold while HHS and the Obama administration reconsidered their accommodation options and tried to satisfy Archbishop Dolan and other critics of the mandate. Meanwhile the bishops' new religious liberty committee intensely lobbied Congress for three bills - the Protect Life Act, the Abortion Non-Discrimination Act, and the Respect for Rights of Conscience Act - that would provide the church the desired exemptions (not accommodations) from 
any laws regarding contraception or abortion [13]. The desired legislation clarified how far the bishops were willing to go in the name of conscience. The Protect Life Act, for example, would have "prevent[ed] women from using their own money to pay for private insurance plans that cover abortion under the new health care exchanges, and it would also allow religious hospitals to refuse emergency care to pregnant women in need of life-saving abortions." [13]. Compromise with the president was not on the bishops' agenda.

The government's next concession appeared in February 2012, when HHS finalized the August 2011 rule while offering an olive branch to the bishops [38]. The government would still follow IOM's recommendations of coverage, and the purely religious employers would still be exempt. In addition, the February 2012 regulations identified a safe harbor period until August 2013, during which the mandate would not apply to "nonprofit organizations with religious objections to contraceptive coverage," while the government figured out how to "develop and propose changes to these final regulations that would meet two goals-providing contraceptive coverage without cost-sharing to individuals who want it and accommodating non-exempted, non-profit organizations' religious objections to covering contraceptive services." ([38], p. 8727). In other words, HHS was promising to find an accommodation for the religious nonprofits. As the following language from the February regulation suggests, HHS was bending over backwards to keep the Catholic nonprofits from having to provide any contraceptive insurance at all:

Specifically, the Departments plan to initiate a rulemaking to require issuers to offer insurance without contraception coverage to such an employer (or plan sponsor) and simultaneously to offer contraceptive coverage directly to the employer's plan participants (and their beneficiaries) who desire it, with no cost-sharing. Under this approach, the Departments will also require that, in this circumstance, there be no charge for the contraceptive coverage...The Departments intend to develop policies to achieve the same goals for self-insured group health plans sponsored by non-exempted, non-profit religious organizations with religious objections to contraceptive coverage...

Nothing in these final regulations precludes employers or others from expressing their opposition, if any, to the use of contraceptives, requires anyone to use contraceptives, or requires health care providers to prescribe contraceptives if doing so is against their religious beliefs. ([38], p. 8728).

The promise of new regulations and the safe harbor provisions could have been interpreted as a positive signal to the bishops that more accommodations were on their way-accommodations that the First Amendment did not require. Instead, the bishops immediately and vigorously rejected the Obama administration's olive branch to the religious nonprofits. They complained that the insurance would still be connected to the objecting employer in some immoral way. They also insisted that any accommodation had to apply to everyone who objected to contraception, whether nonprofit or for-profit, secular or religious, corporation or individual $[39,40]$. Indeed, the bishops did not want any religious accommodation; they wanted the complete exemption from the law that the churches enjoyed to be applied to any employer or individual employee who had moral objections to contraception.

The bishops' lobbying tactics illustrated the argument that "religious interest groups seek outcomes that are entirely different from classic interest groups." ([41], p. 1065). Whereas traditional lobbyists 
view compromise as part of the political process necessary to achieve results, "[f]or the religious lobbyist, the only acceptable outcome is a policy that reflects the religiously driven policy being presented," and "compromise is impossible." ([41], p. 1067). In negotiations between a president seeking compromise and bishops refusing to budge, the bishops' victory became inevitable.

It was at this point, mid-2012, that the bishops launched their strongest campaign against reproductive freedom, by, ironically, arguing that the Obama administration had declared a war on religious freedom to which they must respond. On 21 May 2012, the University of Notre Dame and forty-two other Catholic schools, colleges, universities, dioceses and charities commenced litigation in twelve federal district courts challenging the regulations under the First Amendment and the Religious Freedom Restoration Act (RFRA) [42]. Although the bishops did not join the lawsuits, they "praised the individual dioceses, charities and schools for defending religious liberty." [42].

The "united front" presented by the joint filings of forty-three lawsuits was intentional; the bishops wanted a show of force to counter the voices of some Catholics, including the Leadership Conference of Women Religious, who had expressed satisfaction with the government's February accommodation [43]. Archbishop Dolan characterized the court filings as a "compelling display of the unity of the church in defense of religious liberty," even though only 12 of the nation's 194 dioceses had sued, and only a "handful" of 200 Catholic colleges and universities participated in the litigation [44].

On 21 June 2012 the bishops launched a two-week nationwide campaign, the "Fortnight for Freedom," which targeted the mandate. Baltimore Archbishop William E. Lori, the head of the bishops' Ad Hoc Committee on Religious Freedom, announced from a pulpit at Baltimore's Basilica of the Assumption that "President Barack Obama's policies are 'morally objectionable' and an attack on religious freedom." [45]. A television ad featuring a "glowering photo of Obama" aired to make the point that exemptions were necessary because religious freedom occurs outside as well as inside churches [46]. The bishops were indifferent to complaints that they were engaged in a partisan campaign against Obama during a presidential election year [47].

Notre Dame and the nonprofits were not the only plaintiffs challenging the mandate. Several for-profit businesses contemporaneously filed suit alleging that the application of the contraceptive mandate to for-profit businesses violated the Free Exercise Clause of the First Amendment as well as RFRA. Just as the nonprofits had demanded the exemption permitted to the churches, the for-profits wanted either a total exemption or the accommodation recently offered to the nonprofits [48]. The bishops voiced support for these lawsuits, which were consistent with the bishops' goals to restrict the contraceptive mandate wherever possible.

Individual Catholics business owners, who, like the bishops, opposed all forms of contraception, were among the for-profit plaintiffs. Other Christian employer plaintiffs opposed only those contraceptives that they believed to be abortifacient. Hobby Lobby, an arts and craft chain store owned by evangelical Christians, and Conestoga Wood, a cabinet manufacturing company owned by Mennonites, opposed only four of the twenty contraceptives recommended by IOM. As a matter of faith, they believe that life begins at fertilization, and therefore consider any contraceptive method that prevents implantation to be an abortion. For this reason they opposed the inclusion of IUDs as well as some hormonal contraceptives like Plan B and Ella in the plan's coverage [48]. Now evangelical Christians and Catholic bishops were finding common ground in litigating against the mandate, whether due to moral opposition to abortion or to birth control. 
The bishops remained unhappy in February 2013, when HHS released the details of the accommodation that had been promised in 2012 [49]. The regulations proposed that nonprofit entities that held themselves out as religious organizations and had religious objections to contraceptive services could request the new accommodation ([49], p. 8462). Each of the newly-accommodated organizations would have to "self-certify" to its insurer that it qualified for the accommodation and list what services it opposed ([49], p. 8462). Self-certification protects religious liberty because it keeps the government from deciding who qualifies for the accommodation by parsing through the entity's beliefs. HHS offered an accommodation and not an exemption because, unlike the churches, the nonprofits' employees were "less likely...to share such religious objections of the eligible organizations.” ([49], pp. 8461-62). Thus, HHS remained reluctant to allow Catholic employers to block their non-Catholic employees from contraception in the name of religious liberty.

Once the self-certification was in the insurer's hand, the insurance company "would assume sole responsibility, independent of the eligible organization and its plan, for providing contraceptive coverage without cost sharing, premium, fee, or other charge to plan participants and beneficiaries." ([49], p. 8462). The insurance company would be required to contact the employees and notify them that it would write up new and independent policies for the insured that provided contraceptive access. Thus, the religious employers were freed from any contact with the contraceptive mandate, and, the government concluded, both reproductive choice and religious liberty were protected.

The bishops did not see it that way. They argued that more consciences needed to be protected from the mandate, including all "conscientiously-opposed individuals, for-profit employers (whether secular or religious), nonprofit employers that are not explicitly religious organizations (even in cases where their objection is religious in nature), insurers, and third-party administrators." [50]. Moreover, they insisted, their religious liberty continued to be burdened by the accommodation itself; the bishops and the Catholic litigants argued that the act of signing the self-certification form identifying their opposition to contraception substantially burdened their exercise of religion. Therefore-with high praise from the bishops - the religious nonprofits went back to court, arguing that the accommodation still required them to "provide, pay for, and/or facilitate access to coverage for these objectionable products and services," thereby substantially burdening their religion under RFRA [51,52].

The bishops also undertook some internal Catholic persuasion aimed at politicians. They mailed out flyers against the mandate to be included in parish bulletins. They organized a national postcard campaign, urging Catholics to contact members of Congress so that Congress would pass the full exemption legislation that the churches desired. They also lobbied Congress to oppose any new legislation protecting reproductive freedom, which was sponsored by women's rights advocates worried about the reach of the new accommodation [53-55].

The intraecclesial debate was secondary, however. The merits would be decided in court. While the religious nonprofits' litigation was on hold as HHS drafted possible accommodations of religion that would render the lawsuits moot, the for-profit corporations' lawsuits requesting a similar accommodation had proceeded. The for-profit cases arrived at the U.S. Supreme Court first when the Court granted certiorari on 26 November 2013, in cases brought by Hobby Lobby and Conestoga Wood challenging the mandate under the First Amendment and RFRA [48]. The bishops' conference filed an amicus brief supporting the for-profits' challenge [16]. 
The Christian and Catholic coalition was successful. The for-profits' victory in the Supreme Court was based entirely on the bishops' earlier success in persuading the Obama administration to accommodate the nonprofits, and the for-profits' success motivated the bishops to keep fighting for more accommodations after Hobby Lobby was decided on 29 June 2014 [48].

\section{Hobby Lobby and Conestoga Wood}

Like the nonprofits, the for-profits challenged the contraceptive mandate as a violation of both the First Amendment and RFRA. In light of Employment Division v. Smith, however, the free-exercise claim was a nonstarter [26]. Just like the women's contraceptive acts in the states, the ACA was a neutral law of general applicability that the for-profit employers were bound to follow.

Smith, however, became a controversial case after it was decided in 1990. Although there was a long, pre-Smith history of Court cases that applied Smith's rule-including the Court's first free exercise opinion - many religious groups and individuals pushed back against the Court's decision. They interpreted Smith as hostile to religious freedom instead of recognizing the opinion as protecting civil rights by requiring all citizens to follow the law equally [56].

With the backing of President Bill Clinton, a broad array of religious groups (conservative as well as liberal), lobbied Congress to pass the RFRA statute in 1993 for the direct purpose of overruling Smith. Under RFRA, if a neutral law substantially burdens religion, the government has to demonstrate that the law serves a compelling government interest and uses the least restrictive means to further that interest. This test was not only the strictest form of scrutiny available in constitutional law, but had never been the law of the First Amendment pre-Smith [57,58]. The RFRA standard made it much easier for courts to invalidate any and all laws that plaintiffs claimed burdened their religion, including the ACA contraception mandate.

Ironically, the Catholic bishops were reluctant supporters of RFRA. Although they lent their support to the pro-RFRA coalition, Mark Chopko, General Counsel of the USCCB, "objected to the original RFRA on the ground that it would lay the groundwork for believers to argue in favor of rights to abortion." [57]. According to Chopko's testimony in the House of Representatives,

The Conference has legitimate concerns that H.R. 2797 will be utilized to attempt to promote the destruction of innocent unborn human lives, and to pit religious groups and individuals against one another in disputes over a variety of social and educational programs as well as tax exempt status [59].

By 2014, however, RFRA was the bishops' strongest weapon against reproductive freedom, and they and their for-profit allies used the statute to "pit religious groups and individuals against one another in disputes" about reproductive freedom. Thus the politicians' passage of RFRA provided the bishops with a victory that the Constitution's First Amendment would have denied them.

For RFRA to be triggered, plaintiffs must establish that they are persons whose exercise of religion is substantially burdened by the government. Once a substantial burden is established, the government must demonstrate that it has a compelling government interest and used the least restrictive means to enforce that interest. In Hobby Lobby, the Court read all components of the statute-persons, who exercise religion, substantial burden, compelling government interest, and least restrictive means - in a 
manner favorable to plaintiffs challenging the contraceptive mandate and consistent with what the bishops had argued throughout the regulatory process and the nonprofit and for-profit litigation [48,58].

As a threshold matter, the Court recognized for-profit corporations as persons who can exercise religion under the statute. Moreover, the Court did not question that the exercise of religion was involved in Hobby Lobby, deferring to the plaintiffs to define their religious exercise. On the substantial burden question, Justice Alito wrote for the majority that it is not for the Court to determine whether a burden is substantial or insubstantial; the moral judgment of the plaintiffs about what is burdensome is controlling. Alito then "assumed" that the government had a compelling interest in protecting women's health and equality in the ACA, yet concluded the government had not used the least restrictive means to accomplish that interest. Therefore Hobby Lobby and Conestoga Wood won their challenges under RFRA [48].

The bishops deserve primary credit for the success of the least restrictive means analysis in Hobby Lobby. The Court ruled that the government could not meet the least restrictive means test because there was another means available to provide contraceptive insurance to employees - namely the accommodation already provided to the religious nonprofits. Thus, it turned out to be foolhardy for the Obama administration to have given into the rhetoric that the nonprofits' accommodation was necessary to end a war on religious liberty. The accommodation of the religious nonprofits led directly to the accommodation of the religious for-profits and the government's loss in the Supreme Court $[48,58]$.

In retrospect, it was the national politicians - not the courts - who had assured the bishops' victory. During the 1990s, the California and New York legislatures had resisted the bishops' pressure to exempt religious nonprofits from the mandate. The state courts had rejected the First Amendment challenges to the contraceptive acts and neither New York nor California had a RFRA. In contrast, Congress passed RFRA in response to a political coalition that included the bishops. Then President Obama abandoned his own mandate soon after the bishops accused him of attacking religious liberty.

The Court's ruling in Hobby Lobby fulfilled one of the bishops' goals to extend the accommodation to all employers. The bishops succeeded by joining with evangelical Christians who opposed abortion (not contraception) - a coalition unimaginable a century earlier, when Protestant Christians had viewed the Catholic hierarchy with so much distrust.

Even before the contraceptive regulations were drafted, however, the bishops had argued for a complete exemption from the mandate, not the miserly accommodation that the Court addressed in Hobby Lobby. They continued to fight for that goal immediately after the Court's ruling.

\section{Notre Dame and the Religious Nonprofits}

When it ruled for the religious for-profit Hobby Lobby on the least restrictive means prong of RFRA, the Supreme Court relied on the government's accommodation of the religious nonprofits to demonstrate that another alternative was available. Some early legal commentary about Hobby Lobby suggested that by mentioning the nonprofits' accommodation, the Court had approved of the accommodation that the nonprofits were still challenging in court. Three days after Hobby Lobby issued, however, the Court ordered the government to provide contraceptive coverage to Wheaton College employees, even though religious nonprofit Wheaton had not signed the self-certification form 
for reasons of conscience. The Court issued an injunction that the mandate could not be applied to Wheaton if the school told the Secretary of Health and Human Services that it objected to contraception. Wheaton College need not use the government form or send copies to health insurers and third-party administrators, as the HHS rule then required [60].

As Justice Sotomayor complained in a blistering dissent, the very accommodation that the Court had just praised in Hobby Lobby was now deemed unacceptable in Wheaton College [60]. Cheered by Wheaton College, the nonprofits continued to litigate the accommodation, arguing that signing the self-certification form notifying the third party insurer of their decision not to cover contraception substantially burdened their religion because it "triggered" coverage for contraception, of which they disapproved. The appeals courts, however, ruled that the nonprofits' religion was not substantially burdened by the signature because the ACA, not the signature, triggered the coverage $[52,61]$.

Nonetheless, HHS made yet another attempt to accommodate the objectors through the regulatory process, this time adopting the Wheaton College approach. This approach allows the objecting corporation to notify HHS directly of its objection instead of contacting the insurance company [62]. After another notice and comment procedure, on 14 July 2015, the Obama administration issued a final rule about the accommodation [63]. According to the final rule, the religious nonprofits may choose to use either the government's self-certification form or the Wheaton College process of notifying HHS in writing. The notice to HHS must include "the name of the eligible organization and the basis on which it qualifies for an accommodation; its objection based on sincerely held religious beliefs to covering some or all contraceptive services, as applicable (including an identification of the subset of contraceptive services to which coverage the eligible organization objects, if applicable); the plan name and type (that is, whether it is a student health insurance plan within the meaning of 45 CFR 147.145(a) or a church plan within the meaning of ERISA Section 3(33)); and the name and contact information for any of the plan's third party administrators and health insurance issuers." [63]. The government will then contact the insurers, who are obligated to provide the contraceptive coverage [63].

As it had throughout the regulatory process, the bishops' OGC filed comments critical of HHS's latest moves. The letter's wording left no question about the bishops' goal; "we continue to believe that the contraceptive mandate should be rescinded." ([64], p. 2). OGC argued again for a broad exemption for "all stakeholders with a religious or moral objection to contraceptive coverage." ([64], p. 2). Finally, it protested the idea that religious for-profits would be accommodated while non-religious nonprofits would not. "Oddly, in the space of one Supreme Court Term, the Administration has gone from arguing that being a for-profit foreclosed religious liberty protection, to claiming that a group without religious affiliation must be a for-profit in order to secure the accommodation," the bishops argued ([64], pp. 4-5). The bishops still wanted a complete exemption for everyone from the contraceptive mandate, indeed, its complete rescission.

\section{Conclusions}

The nonprofit cases have continued through the courts. Seven of eight U.S. courts of appeals rejected the argument that the notification provisions of the accommodation substantially burden plaintiffs' religion under RFRA. On 6 November 2015, the United States Supreme Court granted 
certiorari to review the opinions of the courts of appeals [65]. A decision from the Court is expected by 30 June 2016. We will learn then the extent of the success of the bishops' campaign against contraception.

\section{Conflicts of Interest}

The author declares no conflict of interest.

$\begin{array}{ll}\text { Abbreviations } \\ \text { ACA } & \text { Affordable Care Act } \\ \text { EPICC } & \text { Equity in Prescription Insurance and Contraceptive Coverage Act } \\ \text { FDA } & \text { Food and Drug Administration } \\ \text { HHS } & \text { Department of Health and Human Services } \\ \text { IOM } & \text { Institute of Medicine } \\ \text { NCCB } & \text { National Conference of Catholic Bishops } \\ \text { NCWC } & \text { National Catholic Welfare Conference } \\ \text { OGC } & \text { Office of General Counsel of the USCCB } \\ \text { RFRA } & \text { Religious Freedom Restoration Act } \\ \text { USCCB } & \text { United States Conference of Catholic Bishops } \\ \text { ACA } & \text { Affordable Care Act } \\ \text { EPICC } & \text { Equity in Prescription Insurance and Contraceptive Coverage Act } \\ & \end{array}$

1. Martha J. Bailey. “'Momma's got the Pill': How Anthony Comstock and Griswold v. Connecticut Shaped US Childrearing." American Economic Review 100 (2010): 98-129.

2. Leslie Woodcock Tentler. Catholics and Contraception: An American History. Ithaca: Cornell University Press, 2004.

3. Gene Burns. The Moral Veto: Framing Contraception, Abortion, and Cultural Pluralism in the United States. New York: Cambridge University Press, 2005.

4. Patricia Miller. Good Catholics: The Battle over Abortion in the Catholic Church. Berkeley: University of California Press, 2014.

5. Griswold v. Connecticut, 381 U.S. 479 (1965).

6. Eisenstadt $v$. Baird, 405 U.S. 438 (1972).

7. Jonathan Eig. The Birth of the Pill: How Four Crusaders Reinvented Sex and Launched a Revolution. New York: W.W. Norton \& Co., 2014.

8. Barry Hudock. Struggle, Condemnation, Vindication: John Courtney Murray's Journey toward Vatican II. Collegeville: Liturgical Press, 2015.

9. John T. McGreevy. Catholicism and American Freedom: A History. New York: W.W. Norton \& Co., 2003.

10. Giuseppe Alberigo, Joseph A. Komonchak, eds. History of Vatican II, Volume V. Maryknoll: Orbis, 2006. 
11. John Courtney Murray, S.J. "Memo to Cardinal Cushing on Contraception Legislation." In Bridging the Sacred and the Secular: Selected Writings of John Courtney Murray. Edited by J. Leon Hooper, S.J. Washington: Georgetown University Press, 1994.

12. Leslie Griffin. "What Might Have Been: Contraception and Religious Liberty." University of St. Thomas Law Journal 1 (2003): 632-46.

13. Laura Bassett. "The Men behind the War on Women." Huffington Post, 1 November 2011. Available online: http://www.huffingtonpost.com/2011/11/01/the-men-behind-the-war-on_n_ 1069406.html (accessed on 19 October 2015).

14. Linda Greenhouse, and Reva B. Siegel. "Before (and After) Roe v. Wade: New Questions about Backlash.” Yale Law Journal 120 (2011): 2028-87.

15. Timothy A. Byrnes. Catholic Bishops in American Politics. Princeton: Princeton University Press, 1991.

16. Supreme Court of the United States. "Brief of the United States Conference of Catholic Bishops as Amicus Curiae in Support of Hobby Lobby and Conestoga Wood Specialties Corp., et al.” 28 January 2014. Available online: http://www.usccb.org/about/general-counsel/amicus-briefs/upload/ amicus-13-354-13-356-sebelius-hobby-lobby-conestoga-wood.pdf_(accessed on 19 October 2015).

17. Internal Revenue Service. "501(c)(3): Tax Guide for Churches and Religious Organizations, Pub. 1828." August 2015. Available online: https://www.irs.gov/pub/irs-pdf/p1828.pdf (accessed on 19 October 2015).

18. United States Conference of Catholic Bishops. "Government Relations." Available online: http://www.usccb.org/ogl/ (accessed on 19 October 2015).

19. The Pew Forum on Religion \& Public Life. "Lobbying for the Faithful: Religious Advocacy Groups in Washington, D.C.” May 2012. Available online: http:/www.pewforum.org/files/2011/ 11/ReligiousAdvocacy_web.pdf_(accessed on 19 October 2015).

20. Brian Galle. "The LDS Church, Proposition 8, and the Federal Law of Charities." Northwestern University Law Review Colloquy 103 (2009): 370-79.

21. Leslie C. Griffin. Law and Religion: Cases and Materials, 3rd ed. St. Paul: Foundation Press, 2013.

22. National Conference of State Legislators. "Insurance Coverage for Contraception Laws." February 2012. Available online: http://www.ncsl.org/research/health/insurance-coverage-for-contraceptionstate-laws.aspx (accessed on 19 October 2015).

23. Catholic Charities of Sacramento, Inc., v. Super. Ct., 85 P.3d 67 (Cal. 2004).

24. Catholic Charities of the Diocese of Albany v. Serio, 859 N.E.2d 459 (N.Y. 2006).

25. Catholic Charities of Sacramento, Inc. v. Superior Court, 2001 WL 1700664 (Cal.), 1 (Cal.Brief, 2001).

26. Employment Division, Dep't of Human Resources of Oregon v. Smith, 494 U.S. 872 (1990).

27. Coverage of Preventive Health Services, 42 U.S.C. $§ 300 g g-13(a)(4)$.

28. Department of Health \& Human Services. "Interim Final Rules for Group Health Plans and Health Insurance Issuers Relating to Coverage of Preventive Services under the Patient Protection and Affordable Care Act." Federal Register 75 (2010): 41726-60.

29. Office of the General Counsel. "Letter Re: Interim Final Rules Relating to Coverage of Preventive Services.” 17 September 2010. Available online: http://www.usccb.org/issues-and-action/ 
human-life-and-dignity/contraception/upload/regarding-interim-final-rules-relating-to-coverage-ofpreventetive-services.pdf (accessed on 19 October 2015).

30. Department of Health \& Human Services. "Group Health Plans and Health Insurance Issuers Relating to Coverage of Preventive Services under the Patient Protection and Affordable Care Act." Federal Register 76 (2011): 46621-26.

31. Exemption and Accommodations in Connection With Coverage of Preventive Health Services. 45 C.F.R. $\S 147.131(a)$.

32. Office of the General Counsel. "Letter Re: Interim Final Rules on Preventive Services." 31 August 2011. Available online: http://www.usccb.org/about/general-counsel/rulemaking/upload/ comments-to-hhs-on-preventive-services-2011-08-2.pdf (accessed on 19 October 2015).

33. National Federation of Independent Businesses $v$. Sebelius, 567 U.S. (2012).

34. United States Conference of Catholic Bishops. "U.S. Bishops Establish New Ad Hoc Committee for Religious Liberty.” 30 September 2011. Available online: http://www.usccb.org/news/2011/ 11-184.cfm (accessed on 19 October 2015).

35. Belmont Abbey Coll. v. Sebelius, 878 F. Supp. 2d 25, 30 (D.D.C. 2012).

36. Laurie Goodstein. "Bishops Open 'Religious Liberty' Drive." New York Times, 14 November 2011. Available online: http://www.nytimes.com/2011/11/15/us/bishops-renew-fight-on-abortionand-gay-marriage.html?_r=0 (accessed on 16 December 2015).

37. David Gibson. "After Obama-Dolan Meeting, Bishops Welcome Dialogue as Concerns Remain." Religion News Service, 15 November 2011. Available online: http://www.religionnews.com/2011/ 11/15/catholic-bishops-open-annual-meeting/ (accessed on 19 October 2015).

38. Department of Health \& Human Services. "Group Health Plans and Health Insurance Issuers Relating to Coverage of Preventive Services under the Patient Protection and Affordable Care Act." Federal Register 77 (2012): 8725-30.

39. Office of the General Counsel. "Memorandum Re: HHS Regulations and Bulletin on Sterilization/Contraception Mandate." 7 March 2012. Available online: http://www.usccb.org/about/ general-counsel/upload/2012-hhs-mandate-public-legal-memo.pdf (accessed on 19 October 2015).

40. United States Conference of Catholic Bishops. "Bishops Renew Call to Legislative Action on Religious Liberty.” 10 February 2012. Available online: http://www.usccb.org/issues-and-action/ religious-liberty/conscience-protection/bishops-renew-call-to-legislative-action-on-religious-liberty. cfm (accessed on 19 October 2015).

41. Zoe Robinson. "Lobbying in the Shadows: Religious Interest Groups in the Legislative Process." Emory Law Journal 64 (2015): 1041.

42. Laurie Goodstein. "Catholics File Suit on Contraceptive Coverage." New York Times, 21 May 2012. Available online: http://www.nytimes.com/2012/05/22/us/catholic-groups-file-suitson-contraceptive-coverage.html (accessed on 16 December 2015).

43. Laurie Goodstein. "Obama Shift on Providing Contraception Splits Critics." New York Times, 14 February 2012. Available online: http://www.nytimes.com/2012/02/15/us/obama-shift-oncontraception-splits-catholics.html (accessed on 19 October 2015).

44. Lisa Miller. "Catholics Caught Between Bishops, Obama's Birth Control Mandate." Washington Post, 24 May 2012. Available online: https://www.washingtonpost.com/local/catholics-caught- 
between-bishops-obamas-birth-control-mandate/2012/05/24/gJQAKv4hnU_story.html (accessed on 19 October 2015).

45. Kevin Rector. "Catholic Leaders Launch Campaign against Obama Policies." Baltimore Sun, 21 June 2012. Available online: http://articles.baltimoresun.com/2012-06-21/news/bs-mdfortnight-of-freedom-20120621_1_religious-freedom-catholic-leaders-health-policies (accessed on 19 October 2015).

46. Mitchell Landsberg. "Catholic Bishops Continue Protest of Contraception Mandate." Los Angeles Times, 21 June 2012. Available online: http://articles.latimes.com/2012/jun/21/news/la-pn-catholic -bishops-continue-protest-of-contraception-mandate-20120621 (accessed on 29 October 2015).

47. Mitchell Landsberg. "Are Catholic Bishops Abandoning Nonpartisanship in Contraception Battle?" Los Angeles Times, 13 June 2012. Available online: http://articles.latimes.com/2012/ jun/13/nation/la-na-bishops-politics-20120613 (accessed on 19 October 2015).

48. Burwell $v$. Hobby Lobby Stores, Inc., 134 S.Ct. 2751 (2014).

49. Department of Health \& Human Services. "Coverage of Certain Preventive Services under the Affordable Care Act." Federal Register 78 (2013): 8456-76.

50. Office of the General Counsel. "Letter Re: Notice of Proposed Rulemaking on Preventive Services.” 20 March 2013. Available online: http:/www.usccb.org/about/general-counsel/ rulemaking/upload/2013-NPRM-Comments-3-20-final.pdf (accessed on 19 October 2015).

51. United States Conference of Catholic Bishops. "Religious Liberty Chair Backs Litigants Opposing HHS Mandate.” 8 April 2013. Available online: http://www.usccb.org/news/2013/13062.cfm (accessed on 19 October 2015).

52. Michigan Catholic Conference v. Burwell, 755 F.3d 372 (6th Cir. 2014).

53. USCCB Nationwide Bulletin Insert. "Pray_Fast—ct." February-March 2013. Available online: http://www.usccb.org/issues-and-action/religious-liberty/conscience-protection/upload/HHS-Bull etin-Insert-5-Pray-Fast-Act-ENG-B-W.pdf (accessed on 19 October 2015).

54. United States Conference of Catholic Bishops. "Project Life and Liberty: Postcard Campaign." Available online: http://www.usccb.org/issues-and-action/religious-liberty/conscience-protection/ project-life-and-liberty-postcard-campaign.cfm (accessed on 19 October 2015).

55. United States Conference of Catholic Bishops. "Dear Senator Letter Opposing Protect Women's Health from Corporate Interference Act.” 14 July 2014. Available online: http://www.usccb.org/ issues-and-action/religious-liberty/upload/07-14-14-S-2578-Cardinal-O-Malley-Archbishop-Lorito-Senate.pdf (accessed on 19 October 2015).

56. Marci A. Hamilton. God vs. the Gavel: The Perils of Extreme Religious Liberty, 2nd ed. New York: Cambridge University Press, 2014.

57. Marci A. Hamilton. "The Case for Evidence-Based Free Exercise Accommodation: Why the Religious Freedom Restoration Act Is Bad Public Policy." Harvard Law \& Policy Review 9 (2015): 129-60.

58. Leslie C. Griffin. “Hobby Lobby: The Crafty Case That Threatens Women's Rights and Religious Freedom." Hastings Constitutional Law Quarterly 42 (2015): 641-93.

59. Religious Freedom Restoration Act of 1991: Hearing on H.R. 2797 before the H. Comm. on the Judiciary, 102nd Cong. 34, 42-43 (1992) (Statement of Mark Chopko, General Counsel, United States Catholic Conference). Washington: U.S. Government Printing Office, 1993. 
60. Wheaton College $v$. Burwell, 134 S.Ct. 2806 (2014).

61. University of Notre Dame v. Sebelius, 743 F.3d 547 (7th Cir. 2014).

62. Department of Health \& Human Services. "Coverage of Certain Preventive Services under the Affordable Care Act." Federal Register 79 (2014): 51092.

63. Department of Health \& Human Services. "Coverage of Certain Preventive Services under the Affordable Care Act. Federal Register - (14 July 2015).” Available online: https://www.federal register.gov/articles/2015/07/14/2015-17076/coverage-of-certain-preventive-services-under-theaffordable-care-act (accessed on 25 October 2015).

64. Office of the General Counsel. "Letter Re: Comments on Proposed Rules on Coverage of Certain Preventive Services under the Affordable Care Act." 8 October 2014. Available online: http://www.usccb.org/about/general-counsel/rulemaking/upload/2014-hhs-comments-on-proposed -rule-on-for-profits-10-8.pdf (accessed on 21 October 2015).

65. Zubik v. Burwell, 136 S.Ct. 444 (2015).

(C) 2015 by the author; licensee MDPI, Basel, Switzerland. This article is an open access article distributed under the terms and conditions of the Creative Commons Attribution license (http://creativecommons.org/licenses/by/4.0/). 